Further Section

Brain Behav Evol 1981;19:214

\title{
Author Index Vol. 19, 1981
}

Aitkin, L.M. 126 d'Ascanio, P. 205

Bass,A.H. 1

Clamann, H.P. 18( Corvaja, N. 205

Doetsch.G.S. 37

Fite, K.V. 144 
Guldin, W.O. 93

Haight.J.R. 17,155,193 Haines, D.E. 108

Kenyon, C.E. 126

Levine, R.R. 56 Lister, B.C. 144

Markowitsch, H.J. 93 Murray, P.F. 17 
Neylon, L. 155, 193

Pearson, J.C. 108 Pritzel, M. 93

Stein, B.E. 180

Towe, A.L. 37

Ziegler.H.P. 56 